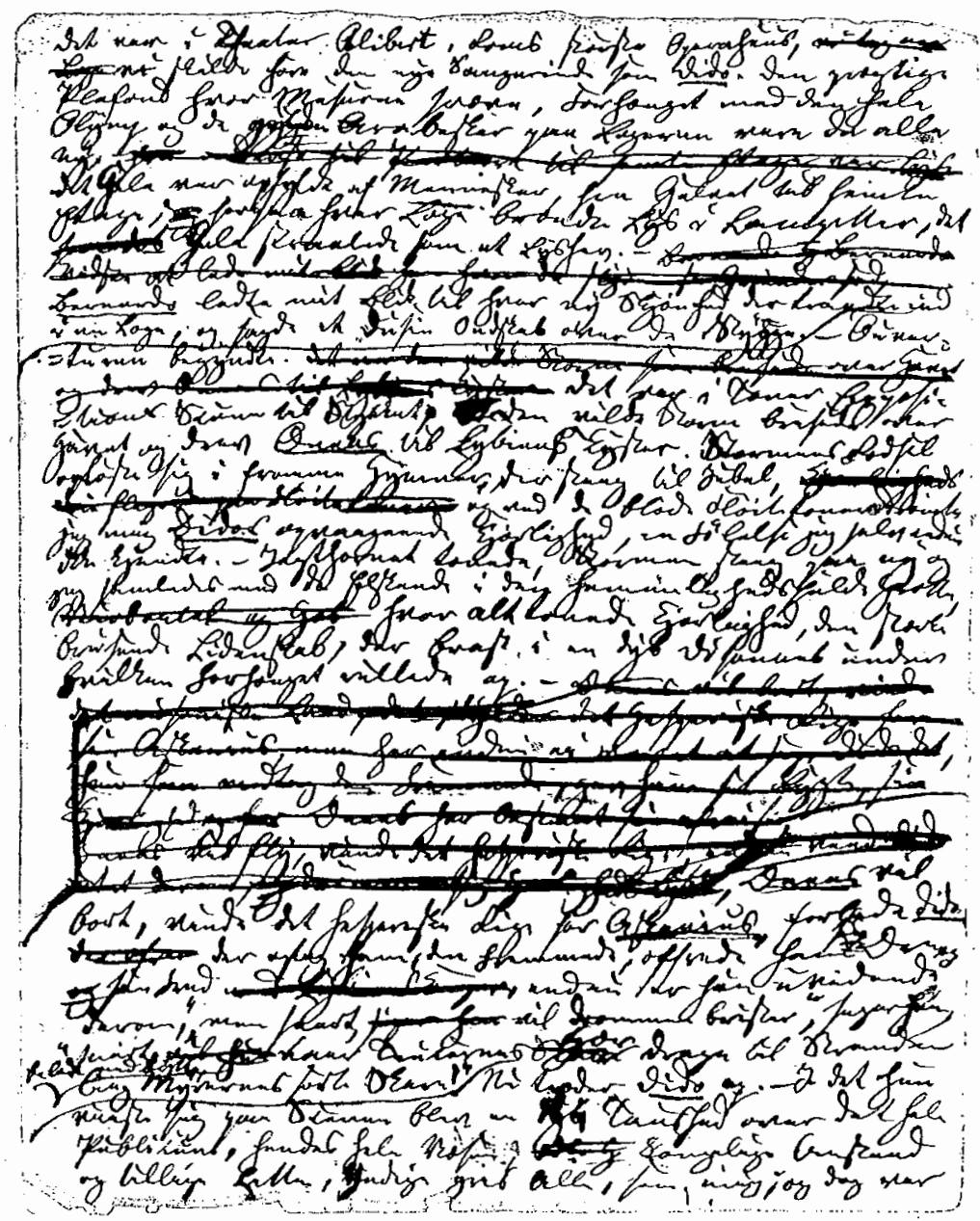

H. C. Andersens renskrift af Improvisatoren.

\section{ROMANENS BLIK}

Et romanteoretisk essay

Frederik Tygstrup

Personerne $i$ mine romaner er mine egne muligheder, der ikke er ble vet realiseret. Derfor holder jeg lige meget af dem alle sammen og derfor skræmmer de mig lige meget: hver af dem har overskredet den grænse, som jeg selv er veget udenom. Netop denne grænse (grænsen, bag hvilken mit jeg hører op) drager mig. Først bag den begynder de hemmeligheder som romanen spørger om. En roman er ikke forfatterens konfession, men en udforskning af hoad menneskelivet er, $i$ den frelde verden er blevet.

Denne lille tekst fra Milan Kunderas Tilværelsens ulidelige lethed formulerer den grundlæggende etik, Kundera forbinder med romankunsten: at den indeholder et erkendelsesperspektiv, der knytter sig til dens særlige æstetiske form. Det følgende er et forsøg på at tage dette romanteoretiske udkast op i en beskrivelse af romanens formelle egenart og af det erkendelsespotentiale, der ligger i romanens evne til at 'overskride' den historiske subjektivitets grænse.

1

I Hegels æstetik er romanen den kunstform, der tydeligst peger på den opløsning af kunsten, som romantikken for Hegel bærer vidnesbyrd om. Med romanen har den æstetiske fremstilling bevæget sig længst muligt bort fral det ideal, hvor kunstens sanselige form var 
det umiddelbare og adækvate udtryk for en oversanselig idé, dens indhold. Romanen tilhører en tidsalder, der ikke længere tillader det ideale at fremtræde i formens sanselige udtryk, en tidsalder, hvor indsigten i virkelighedens sande totalitet alene tilfalder den spekulative erkendelse. Den dramatiske og lyriske form har for Hegel endnu bevaret en tilknytning til den ideale sfære, dramaet i kraft af sin ubrydelige enhed, den lyriske digtning i kraft af sit fortættede, intelligible univers. Dramaet og lyrikken er for Hegel sandere kunst end romanen, men bliver dermed tillige historisk usande, fordi de stræber mod en totalitet, som ikke længere kan fremstilles i den æstetiske form. Romanen bliver paradoksalt den sandeste kunst fordi dens kunstfremmede, 'urene' form, dens afstand til det ideale, på sandeste måde reflekterer, at det ideale ikke længere er tilgængeligt for formen; romanen har sin historiske sandhed deri, at den "er den kunstform, der svarer til en prosaisk indrettet verden"1.

Dette billede af romanen, af dens problematiske forhold til det ideàle og dens formelle forskellighed fra de andre litterære kunstformer, går igen i Georg Lukács' ungdomsværk Theorie des Romans fra 1914, blot med en væsentlig modifikation, der forandrer teoribygningen grundlæggende. Overfor fortrøstningsfuldheden i Hegels tænkning, at den helhed, der udgør sandheden om den historiske virkelighed, lader sig erkende, omend det ikke længere er kunsten beskåret at varetage denne erkendelsesfunktion, sætter Lukács en skeptisk position, inspireret af den nykantianske erkendelseskritik. I stedet for at følge den hegelianske historisering af åndens frembringelser, der ser de forskellige former - om det er kunstens eller tankens - som trin i en proces, hvor sandheden modnes i det historiske, og hvor de enkelte trin derfor artikulerer én og samme sandhed, som de forholder sig til på forskellig måde, anlægger Lukács i Theorie des Romans et diametralt modsat synspunkt: at sandhedsfiguren selv er historisk, dvs. at de forskellige epoker orienterer sig efter hver deres sandhed, at de har hvert deres 'transcendentale landkort'. Sandheden ophører således med at være en overhistorisk topografi, som tankens og kunstens former bevæger sig igennem, og opløser sig i stedet i en række lokale topografier. Hos Lukács - den unge, førdogmatiske Lukács, vel at mærke - er historien ikke i sandheden; omvendt er sandheden selv en historisk figur.

Denne historiske skepsis forhindrer dog ikke Lukács i med Theorie des Romans at give et vældigt og énhedsmæssigt rids af den vesterlandske idéverdens udvikling, for dermed at bestemme romanen som et moment i denne udvikling: énheden er blot ikke længere fremstillet som modningen af en gennemgående sandhedsfigur, men derimod som en gennemgående søgen efter sandheden. På denne baggrund kan Lukács, et århundrede efter Hegel, præcisere romanens stilling i den prosaiske, moderne verden: "Romanen er den gudsforladte verdens epopée"2. Romanen er som æstetisk form knyttet til den moderne verden, hvor den er et priviligeret redskab til at erkende og fremstille de veje, som eftersøgningen efter sandheden tager i en verden, der har mistet den transcendentale sandhed.

Lukács beskriver hvordan efter-renæssancens sækulariserede verden ikke længere ejer et transcendentalt landkort, med hvilket man kan orientere sig i den empiriske verden; det empiriske og det transcendentale er trådt ud fra hinanden, og efterlader et spaltet subjekt. Billedet af mennesket bliver et billede af dets anden natur, dvs. et billede der beskriver hvordan det tager sig ud, men i dette 'hvordan' ikke længere indbefatter et 'hvorfor', ikke længere indeholder meningen bag billedet. Subjektets "anden natur" bliver, med en af de berømte formuleringer i Theorie des Romans, et "stivnet meningskomplex, der er blevet fremmed og ikke længere kan fremkalde nogen inderlighed, et Golgatha for den formodede inderlige, der kun ville kunne vækkes til live gennem en metafysisk genfremkaldelse af det sjælelige" 3 . Eftersøgningen efter en sandhed formidler sig med dette gådefulde dobbeltbillede som en eftersøgning efter den instans, der kan holde de to komponenter sammen i ét.

Billedet af romanen som den kunstform, der svarer til en prosaisk verden, får dermed et andet indebyrd end hos Hegel; dens 'svaghed', fraværet af dramatisk énhed og lyrisk bestemthed, bliver udtryk for formens erkendende konfrontation med en verden, der ikke længere forudkonterer forsoningen mellem det ydre og det indre.

På denne måde kan Lukács præcisere det hegelianske billede af romanen som "den borgerlige tidsalders epopée": den er ikke længere det, der bliver tilbage af kunsten når dens funktion efterhånden erstattes af spekulationen, en 'rest' af epopéen, der er længe om at dø $\mathrm{ud}$, men "den modnede mandigheds form" 4 . Romanen konfronterer sig med det moderne univers, sådan som det præsenterer sig for erfaringen: den undgår spekulationens abstrakte overvindelse af den menneskelige livsverdens spaltning, og fastholder dermed den sanselige form; men den gør dette uden i det samme at oprette et metafysisk flugtpunkt, som formen henviser til. Romanens mandhaftige modenhed er en konfrontation med sporgsmålet om sandheden; dens ubegrænsede univers gennemlyser en endelig verden, en verden uden "metafysisk trøst", og hvad den kan finde er ikke en sandhed, der åbenbarer sig (sådan som spekulationen vil det, idet den antager at sandheden findes et sted, og blot venter på at blive ud- 
grundet af en refleksion, der er spidsfindig nok), men derimod sandheden om det univers, hoor sandheden ikke længere lader sig hævde som absolut.

Lukács' udgangspunkt for at 'rehabilitere' romanen overfor den filosofiske æstetiks lidt stedmoderlige behandling er denne historiefilosofiske bestemmelse af sandhedens problematiske figur i den moderne verden. I det følgende skal jeg fremhæve to af de for mig at se vigtigste træk i Lukács' begreb om romanen: for det første den æstetiske form, romanen udefra betragtet udgør, for det andet det univers, romanen fremstiller.

Jævnfører vi igen med dramaets og poesiens ideale former, er der i begge tilfælde tale om lukkede, afrundede former, der hver på deres måde tildanner et immanent univers, som pr. tradition forudsætter, at en dramatisk handling kan betragtes som en énhed, respektive at det lyriske værk kan danne en sluttet meningssammenhæng. Romanen har imidlertid ikke adgang til en sådan på forhånd sat formel stemthed; den råder ikke over en form--kánon, der kan sammenlignes med f. eks. tragedien eller sonetten. Udefra betragtet er romanen først og fremmest en repræsentation af et givet univers. Denne bestemmelse er til gengæld ikke éntydig i den moderne verden, eftersom der, som vi har set, ikke findes en énstemmig transcendental sandhed, der kan regulere denne repræsentation. Romanen repræsenterer, uden på forhånd at kende repræsentationens lov. Som æstetisk form fremstiller den et afrundet univers, samtidig med at denne fremstilling ikke har nogen regel. Romanen går imidlertíl ikke til grunde på denne apori: den møder den og markerer den i formen. Romanen repræsenterer verden i et dobbelt perspektiv: dels et direkte, den umiddelbare fremstilling, dels et indirekte, der fremstiller den første repræsentations 'selvkorrektur', markerer at romanen adskiller sig fra andre fremstillinger ved refleksivt at repræsentere repræsentationen.

Denne refleksive egenskab skal jeg komme tilbage til nedenfor (afsnit 8); først skal jeg knytte nogle flere bemærkninger til den anden egenskab ved romanen, der fremgår af Theorie des Romans: a den indfører en særlig måde at repræsentere det moderne univers på.

I repræsentationen af den moderne verden er romanens perspektiv éntydigt den menneskelige livsverden, den subjektive konfrontation med det endelige og ubegrænsede univers. Denne konfrontation er imidlertid ikke normeret; den aftegner et form-princip for romanen, men den bestemmer ikke et form-mønster. Konfrontatio- nens udgangspunkt er ikke en verden, der lyder visse fundamentale regler - gudernes vilje, det godes sejr, osv. - , men en kontingent verden, en prosaisk, gudsforladt verden. Romanens repræsentation af konfrontationen mellem subjektet og verden har med andre ord ikke et olympisk synspunkt, der ligger 'over' konfrontationen, et sted, hvorfra den kan betragte og fremstille den. Den kan alene se konfrontationen fra subjektivitetens sted; denne solidaritet med det subjektive princip kan imidlertid heller ikke fixere nogen regel for repræsentationen, eftersom subjektivitetens billede selv er problematisk. Den subjektive pol i konfrontationen står ikke selv i hel figur, eftersom det netop er manglen på subjektivitet i bestemt forstand, som en énhed af ydre og indre, der er konfrontationens drivkraft. Det subjektive princip er ikke en velkendt subjektivitet, men netop et spørgsmål, spørgsmålet om hvordan subjektiviteten kan træde i karakter.

Udgangspunkt for romanens repræsentation er med andre ord en dobbelt ubestemthed: konfrontationen mellem en kontingent verden og en problematisk subjektivitet. Den æstetiske forms énhedspræg er ikke givet med romanens stof, med konfrontationens to poler i sig selv. Den organiske form, der karakteriserer romanens æstetik, opstår først hvor de to poler sættes i spil, i konfrontationen mellem den kontingente verden og det problematiske subjekt som en dynamisk, processuel udfoldelse.

Som formprincip adskiller denne bestemmelse sig igen fra de øvrige litterære former, idet den énhedsmæssige æstetiske totalitet ikke viser tilbage til et statisk formskema; énheden er givet med processen selv, med den narrative udfoldelse af konfrontationen. Den formelle énhedskarakter er med andre ord ikke afhængig af bestemte tematiske, omfangsmæssige, synsvinkelmæssige eller andre formaliserbare kriterier, men af de udvekslinger og udviklinger, der aftegner sig i konfrontationen mellem en kontingent verden og en problematisk subjektivitet. Den formelle bestemmelse af romanens æstetik kan således ikke gives direkte, som visse velafgrænsede formelle træk; bestemmelsen er indirekte, afledet: en konkret udfoldelse af flugtlinierne i et bestemt problematisk felt.

Denne konkrete udfoldelse har imidlertid en forholdsvis velafgrænset historisk form: biografien over den subjektive dannelse i verden. Den biografiske! form med sin tilstræbt organiske karakter bliver mønster for romanens historiefilosofisk afledede form, og det felt, romanen udfolder, det man bredt kunne kalde subjektivationens problematik i den moderne verden. 
I romanens udvikling er Cervantes' Don Quixote fra 1604 skelsættende; med Don Quixote indvies romangenren som den særlige form, hvormed den episke prosa træder ind i moderniteten.

Den før-moderne epopées beretning om heltens rejser og oplevelser bærer vidnesbyrd om et gennemsigtigt og meningsfyldt univers. Begivenhederne er underlagt en streng og retfærdig verdensorden som epopéen giver et indblik i. Epopéen repræsenterer, ligesom romanen, et univers og en følge af begivenheder; denne episke repræsentation er imidlertid af en særlig karakter. Epopéens repræsentation af verden er lutret ved en ideal orden, repræsentationen indebærer et hierarki, hvor alle begivenheder viser tilbage til en transcendent og mytologisk orden, der indeholder sandheden bag de fortalte begivenheder. Epopéen er ikke forpligtet på begivenhederne, men på det evige univers, der viser sig bag dem. Den indebærer ikke en fortolkning af verden, tværtimod fortæller den, hvordan verden i virkeligheden er: den rekonstruerer ikke verden, men konstruerer den i overensstemmelse med den guddommelige orden, som muserne åbenbarer for den episke digter.

Når Don Quixote drager ud på sit togt er hans udgangspunkt identisk med epopéens: hans liv som halvgammel rentier omgivet af ridderromaner har fyldt hans bryst med episk sandhed; romanernes eventyrlige og begivenhedsrige liv har i kontrast til hans stillestående eksistens, der ikke lever, vist ham det sande liv — ridderlivet. Når han bryder op og påbegynder sin epopée, begiver han sig ind i sandhedens verden. Han forlader den verden, som åbenbarer sin sandhed i den uvirksomme eksistens' kummerlighed, og begiver sig ind i den verden, der åbenbares af en sandhed, oplyses af epopéens evige sandhedsskær.

Don Quixotes togt er episk i sit udspring og i sin idé, og det kunne have været realiseret som epopée, fortælles det. Han lader sig imidlertid ikke nøje med epopéen; togtet skal føres ud i livet - eller rettere: føre ham ind i det virkelige liv. Dermed bliver togtet en rejse, der som vejmærker har polerne litteratur og virkelighed. Den udtrykker en dobbelt kategorifejltagelse af dem, Don Quixote er mester i: han vælger epopéen fremfor livet, men kræver tillige at leve epopéen. Han foretrækker litteraturen for livet, men tilbagekalder straks denne prioritering idet han netop kræver livet af litteraturen. Litteratur for liv og liv for litteratur: dette er Don Quixotes 'double-bind'.

Den verden, Don Quixote begiver sig ud i, er en verden i ulave. Hans første opgave er derfor ikke at bekæmpe det onde eller give det gode oprejsning; dette er ganske vist den vandrende ridders for- nemme kald, men forud for denne kompromisløse kamp gælder det om at bestemme, hvad der er det gode og hvad der er det onde. Før Don Quixote kan tage affære må han dechiffrere verden, fixere dens betydninger og gengive den en oprindelig klarhed, hvor det gode og det onde indgår i en ideal balance.

Orden, det er for Don Quixote et begrænset univers, der kun indeholder en vis mængde elementer - de elementer der optræder i ridderromanerne. Dette begrænsede univers er styret af en række love, der ligger udenfor det som et forsyn, og Don Quixotes mission er at restaurere den rette lovmæssighed ved at kalde tingene ved deres rette navn. Don Quixotes projekt gentager epopéen, men på hovedet, så at sige: hvor epopéen var en beretning, der skulle levendegøre de virkelige, urhistoriske tildragelser, da sætter Don Quixote sig for at levendegøre beretningen ved at fylde dens elementer med virkelighed. Don Quixotes episke projekt drager i felten mod en verden, hvor ordene og tingene 'ikke passer sammen', - om det er vindmøller, der ikke er de kæmper, som ridderen forventes at bekæmpe, landevejskroer, der ikke er slotte eller fåreflokke, der ikke er fjendtlige hære. Ordene og tingene mødes ikke længere i et fælles væsen, der lader dem være forskellige fremtrædelser for det Samme, hvor "verden er stor og dog som det egne hjem, eftersom den ild, der brænder i sjælen, er af samme beskaffenhed som stjernernes $^{\prime \prime} 5$. Don Quixotes rejse er en rejse ud af epopéens før-moderne verden, der afslører, at tegnenes udtryksside har revet sig løs fra betydningerne, og deres indholdsside ikke er, hvad de giver det udseende af. Den omvendte epopée, der skal indgive de døde tegn liv, er en transposition af epopéen til et univers, der ikke længere deler dens forudsætninger.

I det omfang Don Quixote indvier romanen som en specifik moderne form, er det hvor den fremstiller den rejse, der fører ridderen ud af det gamle, begrænsede men uendelige univers, hvor epopéen hørte til, og ind i modernitetens ubegrænsede, men fundamentalt endelige verden. $\mathrm{Og}$ tilsvarende bliver Ridderen af den Ulykkelige Skikkelse romanfigur idet han konfronteres med den moderne verden, hvor tegnene ikke er, hvad de betyder, og hvor betydningerne aldrig er der, hvor de burde være.

Don Quixote rejser ind i en verden, der ikke længere er forankret $\mathrm{i}$ en ideal orden, der kan være en fælles reference for ordene og tingene. I fraværet af denne orden viser der sig en sprække mellem de to, mellem verdens prosaiske og epopéens ideale univers. Det er dette mellemrum, romanen indtager og befolker ${ }^{6}$. 
Romanens imaginære rum har ikke længere et idealt midtpunkt; det er erstattet af den forskruede borger, der drager ud i den prosaiske verden. Dermed står rejsen ikke længere i sandhedens tegn; snarere pendler den mellem to: den episke og den prosaiske sandhed. Mod den prosaiske sandhed, at han kæmper mod vindmøller, indvender Don Quixote, at det ganske vist ligner vindmøller, men at der ikke desto mindre, i overensstemmelse med den epopée, han fører ud i livet, er tale om forheksede kæmper. Som i epopéens platoniske verden er alting i Don Quixotes univers kopier, de har alle deres sande forbilleder; blot forekommer der både gode og dårlige kopier. Don Quixote er selv en god kopi af de bedste riddere, mens de ting, der ikke ligner det, de i virkeligheden er, er dårlige kopier, simulakrer.

Subjektets figur står i centrum af romanens rum, for så vidt det er med subjektet som focus, den gennemtrækker det moderne univers. Men samtidig er det et sært centrum, eftersom der ikke knytter sig en éntydig sandhed til den forskruedeborgers færden; den prosaiske og den episke sandhed står overfor hinanden, uden at romanen er i stand til at hævde den ene af dem på den andens bekostning. Måske er det derfor Don Quixote altid er ledsaget af Sancho Panza. Sancho er den prosaisk-snusfornuftige; han tænker på sin betaling, på mad og drikke og på de tærsk, han får, mens Don Quixote alene har sig den ædle ridderhåndtering og dens ærefuldhed for øje, og hverken kender til gridskhed, behov eller frygt. Men ikke desto mindre er det Sancho, der ligger under for illusioner og overtro, idet han fastholder sin tro på, at Don Quixote vil gøre ham til guvernør over en $\varnothing$, og taler vidt og bredt om hvor glimrende han vil udfylde denne position, alt imens Don Quixote selv med pragmatisk tålmodighed konfronterer sig med den forheksede verden, der møder ham. Også i denne forstand er Don Quixote og Sancho Panza uadskillelige; det gælder respektivt for dem begge, at den anden ikke alene er den anden i parret, han er tillige - og først og fremmest - den anden til ham selv, hans eget Andet. Ingen af dem har nogensinde ret, ingen af dem har sandheden på sin side, - og denne usandhed overfører de gensidigt til hinanden, således at sandheden om den ene altid befinder sig udenfor ham selv, som den andens usandhed, og vice ver-

Subjektet danner et centrum i romanens univers, men der er tale om et paradoksalt centrum, fordi det ikke er identisk med sig selv subjektet har både en prosaisk og en episk sandhed, er spaltet i en empirisk og en transcendental komponent. Romanens centrum er ude af sig selv.
Den erfaring af moderniteten, der aftegnes i Don Quixote, peger på at romanens udgangspunkt, subjektivitetens figur, er problematisk: subjektet, der ikke længere er dannet i Guds billede, er ikke identisk med sig selv, og dets sandhed er ikke Sandheden, men en perspektivisk sandhed, hvis patos kan variere fra det tragiske til det komiske. I romanens 'store' århundrede, fra Richardson til Flaubert, kan udviklingen af formen anskues som en udvikling af repræsentationsmodeller, der rejser billedet af verden via biografiens organiske form, og dermed som en række forsøg på at fremstille subjektiviteten på en måde, der kan bøje dets problematiske, ikke identiske elementer sammen i en hel figur.

Den sentimentale opdragelsesroman - den engelske romance og eventyrromanen lod subjektiviteten træde op mod den indre og den ydre uendelighed, og prægede dermed en figur, der kan repræsentere den subjektivitet, hvis spaltethed forbyder en 'direkte' repræsentation: erfaringen. I konfrontationen med den indre og den ydre verden træder subjektet i karakter som subjekt for en erfaring. Claus Bratt Østergaard har overbevisende demonstreret, hvorledes Pamelas udvikling i Richardsons roman (Pamela) er formidlet gennem en række retoriske tilnærmelser til kønnet; idet hun efterstræbes som et køns-objekt erfarer hun diffust sig selv som potentielt subjekt for en seksualitet, og afdækker hermed en indre dimension i selvet, som romanens univers er bygget op om. En tilsvarende erfaringsformidlet rejse ud i den ydre verden har Bratt Østergaard påpeget i Defoes Robinson Crusoe, hvor Robinson flygter hovedkuls fra den gamle verden, og først finder sig selv i stofskiftet med naturen, i arbejdet, hvormed han erkender sig selv som subjekt for en civiliserende bestræbelse, og ikke længere alene som objekt for en social orden?.

Den spaltede subjektivitet viser sig på én gang som objekt $i$ en verden og som subjekt for en verden; i forestillingen om den subjektive erfaringsproces, hvor der etableres en dynamisk formidling mellem objektivt og subjektivt, kan romanen fremstille et helt subjekt, hvis helhed ikke er en statisk, given totalitet, men en helhed, der opstår i og med erfaringens integrerende proces. Hvor den tidlige roman med Don Quixote bar vidnesbyrd om subjektivitetens problematiske natur i det moderne, hvor den subjektive position var underlagt en paradoksal fordoblingslogik og helten måtte være to - Don Quixote og Sancho Panza, eller Jacques og hans herre hos Diderot - , foreslår den senere roman en 'løsning' på dette paradoks ved at lade den Ene danne sit subjektive rum i erfaringens proces med det Andet. Med den store borgerlige roman er der gået 
dialektik i forholdet mellem herre og træl.

Romanen kommer til at tegne et univers, hvor den subjektive dannelse bliver den drejeskive, i forhold til hvilken verden lader sig repræsentere. I dannelsesromanens tradition tager den biografiske form udgangspunkt i den ydre og indre ubestemthed: et subjekt, der står overfor en verden, der kan indtages, og en sjæl, der kan udforskes. Romanens helt bliver den unge mand, der er udstyret med to første omgang abstrakte egenskaber: dynamik og inderlighed, som i dannelsesprocessen konkretiseres og subjektiveres.

Det store, harmoniske billede af denne dannelsesproces leverer Goethes Wilhelm Meister; den unge mand begxrer at indtage verden, kaster sig ud i den for at realisere sin bestemmelse, sit kald. Den proces, han dermed starter, er imidlertid ikke alene en virkeliggørelse af begæret. Den bestemmelse, som begæret artikulerer, er nemlig alene en subjektiv bestemmelse, begæret alene et umiddelbart begær; dannelsen indebærer hos Goethe mere end realiseringen af en bestemmelse, nemlig en modnet indsigt $i$ den subjektive bestemmelses objektive indhold. Realiseringen af begæret kontrapunkteres og korrigeres af en fortløbende erfaringsproces. Dette dobbeltsidede forløb, hvis totalitet udgør den eftertragtede dannelse, virkeliggør den subjektive impuls, således at den bringes $\mathrm{i}$ overensstemmelse med de objektive vilkår. Wilhelm Meister artikulerer sin personlighed ved at lægge det ungdommelige brushovede, han var, bag sig, og være i stand til at realisere den person, som hans erfaring gør ham til.

Dannelsen aftegner den ideale ligevægt mellem det umiddelbare begær og den middelbare erfaring, og indeholder dermed en forsoning, den subjektive forsoning med de objektive vilkår, den unge, dynamiske og inderlige mands forsoning med den gældende verdensorden. Hos Goethe har denne forsoning nærmest naturhistorisk karakter, idet Wilhelms dannelse er som en vækst, der lader de kim, der ligger i hans personlighed, bringe til deres ideale udfoldelse; i stedet for at følge det umiddelbare begærs impuls frem mod den forhastede blomstring og følgende misvækst, ledes Wilhelms vej umærkeligt af et dannet frimureragtigt selskab frem langs livsklogskabens gyldne middelvej.

Et sådant billede af dannelsen foretager en fixering af subjektets billede i den moderne verden; dannelse i denne forstand er en forsoning mellem subjektets egen, episke sandhed og verdens prosaiske love. Overfor den tvetydighed og lurende meningsløshed der ledsager subjektiviteten i den moderne, gudsforladte verden, er det dialektisk-ophævende og forsonende dannelsesprojekt en procedure, der kan indsætte subjektet som midte i denne verden. Romanen re- præsenterer subjektet $\mathrm{i}$ et dobbelt greb, der bøjer den episke og den prosaiske sandhed om subjektet sammen i ét billede. Denne egenskab giver - som Franco Moretti har understreget ${ }^{8-}$-romanen en særlig status, idet den fremstiller en socialiseringsmodel, der artikulerer kontradiktionen mellem subjektets episke og verdens prosaiske sandhed, og i det samme aftegner en overvindelse af splittelsen i dannelsens figur, der interioriserer kontradiktionen.

6

Dannelsesromanen bringer et formelt paradigme til udfoldelse, der kan repræsentere subjektiviteten i det moderne; som narrativ struktur kan dette paradigme betragtes som en sammenføring af to principper: et finalitets-princip og et transformations-princip.

Det første manifesterer sig i det overordnede plot; hvor den yderste afgrænsning af den biografiske form er givet med fødsel og død, artikuleres denne kurve kvalitativt med subjektivationens proces, hvor $S_{1}$ forandrer sig til $S_{2}$ over en given tid: Odysseus vender hjem til Itacha, Wilhelm når erkendelsens modenhed, Pamela bliver gift... Det andet, transformationen, er selve det formprincip, der tegner romanens univers ${ }^{9}$. Transformationen er den proces, der danner og konkretiserer subjektivitetens billede i den refleksive konfrontation mellem subjektet og det ydre og indre univers. Mens finaliteten formaliserer strukturen $\mathrm{i}$ - med Claude Bremonds begreber 10 - den fortalte fortælling, tilhører transformationen tilsvarende den fortællende fortælling. Transformationen er romankunstens variationsprincip, og dermed den motor i fortællingen, der udfolder overgangen fra $S_{1}$ til $S_{2}$ som en kontinuert, dynamisk proces.

Paul Ricoeur har - i værket Temps et Récit - beskrevet denne sammenføring som en konfiguration af tiden, og dermed understreget den centrale placering, tiden har i romanens univers. Man kan kort - med Kant - rekapitulere tidens moderne form som et paradoksalt, dobbeltsidigt medium: på den ene side er tiden et transcendentalt vilkår, den ubønhørlige nedtælling mod døden, men på den anden side samtidig en tid, som subjektet træder i karakter i. Subjektet spaltes i et ' $\mathrm{mig}^{\prime}$ ', der forandres i og med tidens gang, dvs. et objekt for tiden, og et 'jeg', der forandrer sig, idet det skanderer tiden som en subjektivationsproces ${ }^{11}$. I den transformative bevægelse fra et udgangspunkt, den unge mand, til slutpunktet, den forstandige borger, hvis erfaring har bragt ham til at kende sig selv og sin sande bestemmelse, får vi et billede af tiden som konkretion, idet alt det, der 'er i tiden' konfigureres som dele af et meningsgivende univers for et subjekt. 
Hvor dannelsesromanen som sit udgangspunkt har konfrontationen mellem den kontingente verden og det problematiske subjekt, danner den på én gang finale og transformative proces en meningsgivende énhed, repræsentationen af det hele subjekt, der bliver ti idet det gør den transcendentale tid til sin tid. Med dannelsesromanen indtager subjektet den gudsforladte verdens centrum ved at vriste tiden fra den meningsløse død og underordne den subjektetes dannelse.

7

Dannelsesromanens ideale form, ligevægten mellem finalitet og transformation, udgør et ideologisk og utopisk princip i harmoniseringen af det kontradiktoriske univers og fremstillingen af et univers med subjektet som centrum. Historisk findes den kun i enkelte højdepunkter af romanens historie, og afløses hurtigt af en ubalance eller en konflikt mellem finalitet og transformation, som hos Novalis, hvor idealet forbliver uopnåeligt, eller hos Balzac, hvor et gigantisk transformationssystem udvisker enhver finalitet. Ikke desto mindre vedbliver dannelsesperspektivet, subjektets tilblivelse som subjekt for sin egen historie og sit eget indre, med at stå i forgrunden for repræsentationen af subjektiviteten, men i negativ, så at sige, som kuldkastet projekt, som desillusionens dannelse, som optegnelse af en verden, der kontrært vedbliver at være et Andet og ikke lader sig assimilere. Dannelsesromanen bliver en roman om dannelsens nederlag, den realistiske roman en roman om det virkeliges mangel på realitet: forsoningsintrigen bliver en splittelseshistorie. Men netop i splittelses- eller desillusionshistorien lever forsoningens optik videre; det er den, der artikulerer splittelsen og desillusionen, gør dem til hvad de er, til forskel fra kontingente udviklinger.

Melvilles Moby Dick er eksemplarisk i så henseende. Kaptajn Ahab's sørejse har al den mytologi og al den realitet, der fandt en fælles form i den store rejseroman; her er det Store Projekt, der skal aftvinge verden dens hemmelighed, tilgængeligt og anskueligt fremstillet i den rige detaljeverden af leksikonartikler og håndelag. Blot er myten om rejsens finalitet hos Melville blevet synlig som myte: en transcendens, der ikke længere åbner sig mod den menneskelige livsverden. Intrigen viser sig alene i negativ, som det "monomaniske indbegreb af alle de skadelige stoffer, som nogle dybttænkende mennesker føler ætse i deres indre, til de til sidst kun lever med en halv lunge og et halvt hjerte..."12. Begærets mål forskanser sig i et arkaisk fravær, og forbinder sig ikke længere med rejsens subjektiverende bevægelse som andet end den rejsendes skygge, der iler ham forud, Rejsen når aldrig til ende, den ydre uendelighed bliver aldrig hjemlig for den, der bestandig rejser videre efter "the whale's spout" i horisontlinien. Opdagelsesrejsen fører verden rundt uden at opdage noget, og alle angreb på de dybe magter afvises; meningens chiffrerede træk forsvinder med hvalen tilbage til oceanets mørke indre, og trækker kaptajnen og hans projekt med sig.

Jo mere verden bliver 'fælde', dvs. jo ringere betydning den subjektive livsverden får, desto mere mening giver romanens repræsentation af en samstemt subjektivitet. Det utopiske billede af dannelsen mister sin tilknytning til en social virkelighed, og dermed sin ideologiske funktion. Konfrontationen mellem det problematiske subjekt og den kontingente verden giver ikke længere anledning til en positiv udvikling, men til en tiltagende disharmoni mellem de to.

Denne forandring i det repræsenterede univers markerer sig tydeligt i en stigende refleksivitet i romanens ydre form. Kaptajn Ahab vil fange den hvide hval, Lykke-Per skabe Europas havn på Jyllands vestkyst, Adrian Leverkühn skabe den absolutte musik: de moderne romanfigurers projekter får noget dæmonisk over sig, og dèt, der for Wilhelm Meister var et kald, bliver en besættelse. Overfor - og parallelt med - den dæmoniske karakter står den ironiske form som allerede Novalis udpegede som et fundamentalt træk ved romanen; i takt med dæmoniseringen af romanens personer accentueres ironiens distance til det repræsenterede projekt, og bliver et bærende formelement hos f.eks. Gide og Broch. Dæmoniens og ironiens figurer foretager en dobbelt markering af det fremstillede ved på hver deres måde at lægge distance til det, og dermed understrege det dobbelte blik, romanen som æstetisk form indeholder.

Dette dobbeltblik er, som nævnt, antydet i Theorie des Romans med sondringen mellem en primær, repræsentativ orden - en orden, der fremstiller subjektets billede i samspillet mellem et finalt og et transformativt moment - og en sekundær, formel orden, der afslutter den æstetiske helhed. Denne sidste er et afgørende moment romanens æstetik, eftersom den repræsentative orden ikke i sig selv danner en afrundet énhed; den biografiske forms organiske totalitet er kun en pseudo-totalitet, hvad enten den er konsonant, som i dannelsesromanen, eller dissonant, som i desillusionsromanen. Under alle omstændigheder er det biografiske perspektiv artificielt, om det er harmonisk eller ej, netop fordi det repræsenterer en subjektivitet, der ikke lader sig reproxsentere. Den æstetiske énhed opstår først da, hvor denne apori reflekteres og romanen markerer en korrektur 
til repræsentationen i den 'ydre' form. Romanens form indeholder begge disse elementer: den artificielle - principielt ubegrundelige - repræsentation, og en refleksion af denne repræsentation, der trækker den umiddelbare realitetseffekt i romanens fabel tilbage ved også at repræsentere denne som repræsentation.

Denne dobbelte markering kan historisk spores overalt i romanens univers; selv hvor finalitet og transformation står i den mest fuldendte balance og fablen har den største, mest 'realistiske' klarhed, optræder refleksionen af den direkte repræsentation, om ikke andet som en understregning af fablens ideale karakter, og dermed som en udpegelse af den periferi, der omgrænser den æstetiske totalitet.

Når romanen ikke, som mange har villet, dør bort i takt med muligheden for at forestille sig en meningsfuld subjektiv dannelsesproces, er det fordi den ikke alene, med sin fabel, repræsenterer denne, men netop indebærer et perspektiv, et blik på det repræsenterede, der ikke er identisk med dette. Kundera har forsøgt at indfange denne dobbelthed med ordsproget "Mennesket tænker, Gud ler"13. Romanens blik er hverken menneskeligt eller guddommeligt, men indtager en eksklusiv position, hvorfra det kan se begge dele, menneskets tænken og gudernes latter. Perspektivet er ikke en synsvinkel i snæver forstand (et udsnit af verden set gennem et temperament...), men heller ikke en position, der indeholder sandheden om det betragtede. Romanen ser det repræsenterede i det perspektiv, at det ikke er i sandheden, og indeholder dette perspektiv i formen.

Når romanen, som det hed i det indledende citat fra Kundera, går over grænsen, er det fordi den overskrider den subjektive position, der repræsenteres; dermed overskrider den imidlertid også den eneste sandhedsposition i romanens univers, nemlig den relative, rent subjektive sandhed, der fremstilles i fablens koordination af finalitet $\mathrm{og}$ transformation. På den anden side af grænsen er der blot ikke en anden, absolut sandhed, som romanen kan konsolidere sig ved; den når ikke frem til et standpunkt, der er mere solidt end den sandhed, der relativeres. Når romanen ikke bryder sammen med den meningsfulde repræsentation, er det fordi den som form kan indtage denne unikke position, ikke længere alt for menneskelig, men heller ikke af den grund guddommelig; den position, der kan se den eneste mulige sandhed i det moderne - at den ikke er i sandheden. Dette er - endnu engang med Kunderas ord - romanens viished. Ikke en simpel fornuft, som den fornuft med hvilken subjektiviteten introniserer sig selv som universets midte, men heller ikke denne fornufts modpol: romanens viished reflekterer fornuften, sætter den i det rette perspektiv ved at lutre den ved dens egen ufornuftighed, der er uadskillelig fra den som en skygge.

Romanens formidable livagtighed i det 20. århundrede, hvor den har overlevet den meningsgivende subjektive énhed, skyldes denne viished, som den bevarer i den æstetiske form. På utallige måder har romanen iscenesat forholdet mellem den tiltagende problematisk primære repræsentation og refleksionen af denne, repræsentationens selvrepræsentation, i en æstetisk afrundet form. Afslutningsvis skal jeg her knytte et par kommentarer til et enkelt værk, Samuels Becketts meget romanagtige fortælling Selskab14, der udfolder romanens formverden på en original og overraskende måde.

'Handlingen' i denne lille tekst er meget enkel: der er én, der ligger på ryggen i mørket, og der er en stemme, der taler til den, der ligger på ryggen i mørket. Stemmen fortæller om en fortid, en nutid og en fremtid, der tilhører den, der ligger på ryggen i mørket og lytter. De fragmenter af en fortid, som stemmen fortæller, kan ikke siges at udgøre en historie; det er konstateringer, syn og billeder i tilfældig orden, erindringens tidsflager, der svæver ukoordineret mellem hinanden. Den, der ligger på ryggen i mørket er tilhører til en række nedslag i hans egen historie, og er således på én gang den, der fortælles til og den, der fortælles. Den subjektive identitet, hvis historie er præsent som erindring og erfaring, er spaltet ud i to positioner: den, som historien tilhører og den, som kan fortælle noget fra denne historie. Den, der ligger på ryggen i mørket, er ikke længere et helt og levende subjekt for sin historie, men er tillige objekt for en anden stemme, der fortæller ham. Spændingsmomentet i teksten er, om de to positioner i lytteren, den, der fortælles til og den, der fortælles, skulle kunne træffe sammen i én:

Et andet træk dens [stemmens] hang til gentagelser. Igen og igen med kun små varianter det samme som for. Som om den dermed ville at han skulle gore den til sit. At han tilstod, Ja, jeg husker. Måske tilmed at han fik en stemme. At han mumlede, Ja, jeg husker. Hvilket bidrag til selskabet det ville være! En stemme i forste person èntal. Som med lange mellemrum mumlede, Ja, jeg husker.15

Hvis den lyttende kunne sige at han var den person, der var tale om i erindringsfragmenterne, hvis han kunne give disse fragmenter en referent, ville det indforre en subjektiv identitet $i$ teksten, en stemme $i$ første person éntal. Hvis erindringsfragmenterne fik et subjekt, ville det være muligt ud fra dem at danne en historie, en biografi.

Så vidt kommer det dog aldrig; muligvis kan man forestille sig, at 
den, der ligger på ryggen i mørket, forsøger at kravle eller vifte en flue væk, selvom dette heller ikke, får vi at vide, er sandsynligt. Den subjektive identitet, der kunne forlene erindringsbillederne med en finalitet, og dermed en anden betydning end den, at de står der at læse, udebliver; de transformationer, der foregår gennem teksten, når ikke så langt som til at holde de to, den, der fortælles til og den, der fortælles, sammen i én identitet. De knyttes aldrig sammen, men forbliver parallelle idet de løst strejfer hinanden.

Den transformative logik, der driver teksten frem, ligger et andet sted. Tekstens dynamik består i en række eksperimentelle opstillinger; den varierer, kombinerer og udvikler de forskellige erindringsflager, udfylder dem som selvstændige figurer, der ikke har deres raison d'être som biografiske fragmenter, men i det enkelte billedes særskønhed. Tilsvarende stilles der ind på lytteren og på taleren $\mathrm{i}$ forskellige vinkler, i udviklingen af en barok, debil koreografi:

Omsider bejæger lad os sige højre knæ sig seks tommer frem idet det derved halverer afstanden mellem sig selv og den homologe hånd. Som så på sin side selv bevæger sig lige så langt. Nu er vor rektangel altså rhombeformet. Men forbliver det ikke længere end det tager for højre knæ og hånd at følge efter. Hvorved rektanglen er genoprettet. Og så fremdeles til han styrter. Af alle former for kravling er denne den krybende pasgang måske den mindst gængse. Og måske derfor af alle den mest underholdende.16

Alle sådanne variationer i teksten har med andre ord et andet subjekt end den disseminerede subjektivitet, der spilles ud i de forskellige positioner: "I et andet mørke eller det samme en anden der forestiller sig det hele for selskabs skyld" (s.12). Måske tilhører rudimenterne af subjektiv identitet, der svirrer omkring mellem den, der fortælles til og den, der fortælles, i virkeligheden den tredje, der forestiller sig det hele, den, der fremstiller og reflekterer de to. Stemmen taler i anden person, og den, der forestiller sig det hele, i tredje person:

Kunne han tale til og om den stemmen taler til og om ville der være være en tredje. Men det kan han ikke. Vil han ikke komme til.17

Denne tredje, den, der mangler, er første person éntal; den, der fortæller og forestiller sig det hele, kan ikke fortælle sig selv. Skriften kan ikke indeholde det subjektive: formidlet gennem skriften bliver subjektet fremmed for sig selv, spalter sig i den skrivende og den skrevne. Samme problem igen, med andre ord. Den biografiske 'ambition' kan ikke realiseres ligeud, subjektet kan ikke skrive 'sig', fortælle sin historie. Derfor er formen i Selskab så betydningsfuld; subjektet kan ikke siges, men dets disparate elementer kan spilles ud i forskellige positioner, og dermed tilnærme det unævnelige jeg.

Måske er Selskab en svag afglans af den store selvbiografiske form, på sporet af den tabte første person éntal. Men biografien kan ikke længere bebo sproget og indtage første person éntal, uden i jeg'et at sammenfatte alt det, der er uforeneligt med det, som Adorno sagde om Slutspil. Til gengæld kan romanen ihukomme biografiens projekt, og dermed være den subjektive identitets anamnese, der erindrer og undersøger, hvad identiteten kunne have været.

Den subjektive identitet kommer ikke direkte til stede $\mathrm{i}$ teksten, hvad der repræsenteres er alene dens 'membra disjecta'; kun formen, der betragter subjektivitetens rester, indeholder stadig noget, der kan ligne subjektets billede. Selskab skriver sig tilbage til det sted, hvor subjektivitetens reducerede omrids kommer til syne, det sted, hvor

ordene er ved at slippe op. Så hvert nyt intetsigende ord er lidt nærmere det sidste. Og med dem også fablen. Fablen om den anden sammen med dig $i$ morket. Fablen om dig der fabler om en anden sammen med dig $i$ mørket. Og hvordan alt taget $i$ betragtning spildt møje og stilhed er bedre. Og du som du altid var. Alene. 18

I denne ensomhed kan romanen påbegynde det, som kulturen har lagt bag sig for længe siden.

Noter:

1. Hegel: Ästhetik, Aufbau-Ausg. bd. 2, s. 452

2. Theorie des Romans, Luchterhands Sonderausg., s. 77.

3. op. cit., s. 77.

4. op. cit., s. 74.

5. Lukács, op. cit., s. 21.

6. Jævnfør Michel Foucaults læsning af Don Quixote i Les Mots et les Choses, s. 60ff., samt Marthe Robert: L'ancien et le nouveau, s. $19 \mathrm{ff}$. 7. Jf. Claus Bratt Østergaard: Romanens Tid, spec. kap V og VI. 8. Jf. The Way of the World. The Bildungsroman in European Culture, 1. del.

9. Transformationsbegrebet stammer fra Chomskys generative grammatik, og er introduceret i romananalysen af Julia Kristeva i Le Texte du Roman fra 1970. 
10 Logique du récit, s. 321.

11. Til denne Kantlæsning, jf. Gilles Deleuze: Differénce et repétition, s. 116 ff. og Paul Riceur: Temps et récit, bd. III, s. 68. ff.

12. Moby Dick, da. ovs. s. $198 \mathrm{f}$.

13. Se L'Art du Roman, s. 193.

14. Compagnie/Company, 1981, da. ovs. ved Uffe Harder, Arena u.å.

15. Selskab, s. 12.

16. op. cit., s. 40

17. op. cit., s. 6.

18. op. cit., s. 52.

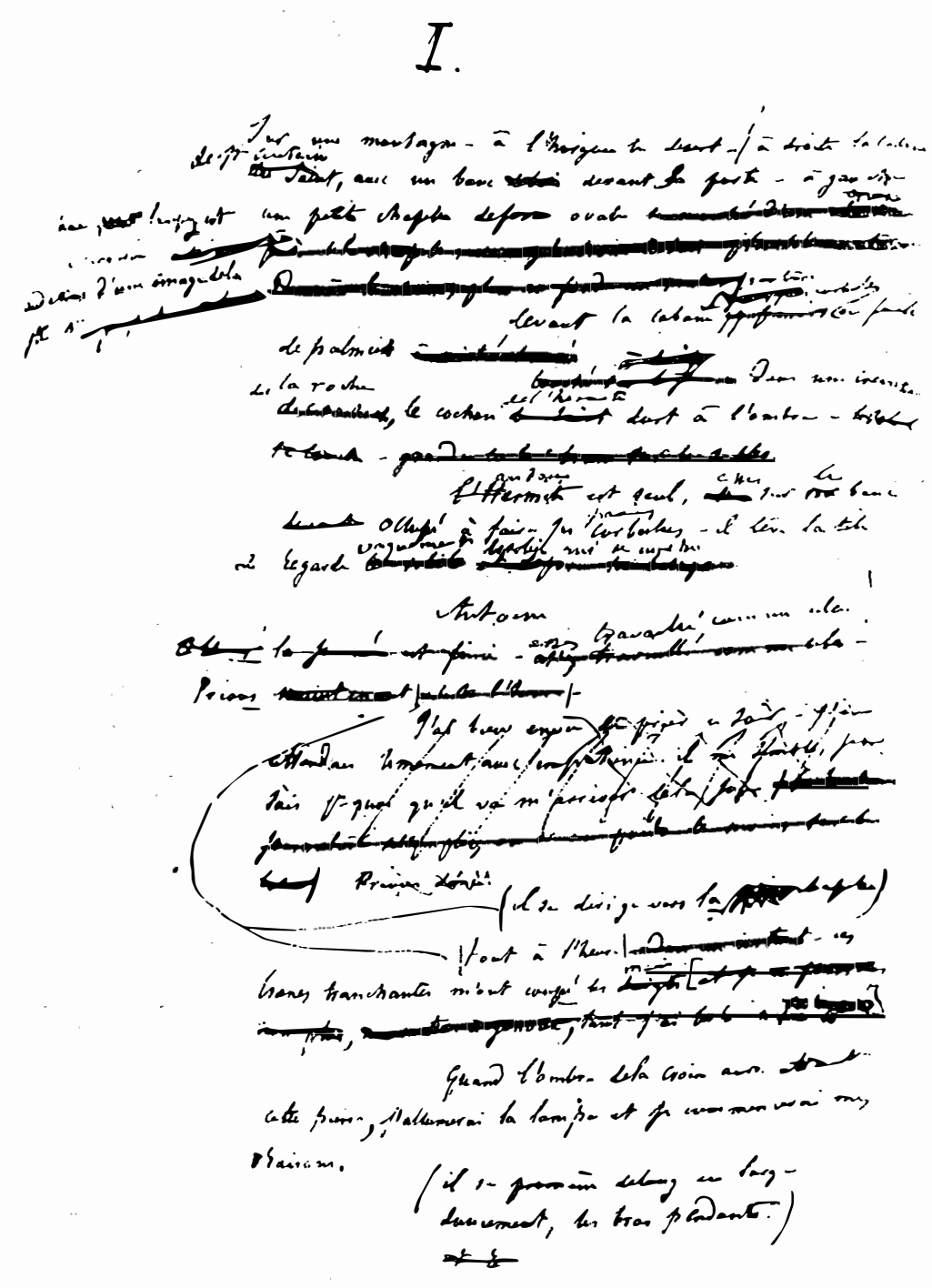

Gustave Flaubert. Fra manuskriptet til La tentation de Saint Antoine. 